\title{
Analysis of Adolescent Developmental Task Mastery and Its Implications for Information Service Materials
}

\section{Dewi Purnamasari}

\author{
Institut Agama Islam Negeri Curup
}

dewipurnamasari@iaincurup.ac.id

Submitted : 2021-07-09, Revised : 2021-11-11, Accepted : 2021-11-24

\begin{abstract}
This study aims to describe the mastery of developmental tasks of MAN Curup students and their implications for the preparation of information service materials. The method used is quantitative with a population of 75 students from MAN Curup majoring in Social Sciences. The sampling technique used is saturated sampling. Data were collected by using a questionnaire using the Guttman scale and analyzed by descriptive analysis. The results showed that some of the tasks of adolescent development have been mastered and some have not been mastered by students. Some developmental tasks that have not been mastered are maturity in establishing relationships with peers, economic independence, choosing and planning careers and understanding and implementing value systems and ethics in behaviour. Some aspects of developmental tasks that have not been mastered by students must be prioritized to be used as a basic reference in program preparation and implementation of counselling guidance services including in compiling information service materials.
\end{abstract}

Keywords: Developmental Task; Information Services; Teenager

\section{Introduction}

Adolescence is a period of transition from childhood to adulthood (Batubara, 2016). At this time, on the one hand, teenagers are in a very beautiful and fun time (Hafiza \& Mawarpury, 2018). Teenagers are starting to get something that has never been obtained before, starting to have close friends, sharing friends, getting experiences and colorful life stories (Mustofa, 2017). But on the other hand, adolescence is also considered the most vulnerable and vulnerable period with problems (Katharina \& Yuliana, 2018). From a physical point of view, adolescents experience growth and development, so that it can trigger anxiety in adolescents (W. R. Pratiwi et al., 2020). In terms of behaviour, adolescents still have a childlike nature even though their physical form has grown and developed like adults, there has been a change in behavioural relationships and an interest in the opposite sex has begun (Fhadila, 2017).

Adolescence in Latin is termed adolescence, which means "to grow or develop" (Fellasari \& Lestari, 2017). This development includes mental, emotional, social, and physical development (Marwoko, 2019). The same view also states that adolescence is basically a period of development towards adulthood (Ali \& Asrori, 2014). Primitive nations view individuals as mature if they are able to reproduce (Nessi Meilan et al., 2019).

Development in adolescence is a very important phase in individual development (Diananda, 2019). Because physical development and will have a direct effect on attitudes and behavior (Fatmawaty, 2017). There are four universal changes that occur in adolescents, namely heightened emotions, body changes, changes in interests and changes in behaviour patterns (Marwoko, 2019). Hurlock explained that teenagers are mostly ambivalent about the changes they experience (Hurlock, 2016).

Adolescence is a period of searching for an identity to shape their personality by trial and error, as a result can cause unpleasant things for adults (Kusuma, 2017). On the other hand, adolescence is a time of "storm and stress" or storm and stress (Khasanah \& Mamnuah, 2021). This is because adolescence are often faced with problems that are difficult to overcome, have internal problems that are difficult to express with others, adolescents insist on solving their own problems according to what they believe and refuse help from others (Y. A. Saputro \& Sugiarti, 2021). 
Theoretically, Hurlock limits that adolescents are in the age range of 13 to 18 years (Hurlock, 2016). Teenagers according to traditional schools are at the age of 13 to 18 years, while the contemporary flow is between the ages of 11 to 22 years (Lestari, 2017). The World Health Organization (WHO) provides a limit for adolescents aged 10 to 20 years (Wahidin, 2017). Meanwhile, the Ministry of Health of the Republic of Indonesia sets a limit for adolescents between the ages of 10 to 19 years and not yet married (Sebayang et al., 2018). In this period, adolescents are faced with various changes and are often associated with stereotypes of deviance and delinquency (Karlina, 2020). Therefore, in the study of adolescent development theory, many theories are found that discuss emotional disorders, behaviour, disharmony and pressure as a result of the changes that occur to him, both physical and psychological changes (Yasipin et al., 2020).

Along with these changes, adolescents are also faced with developmental tasks that are very different from previous developmental tasks or childhood (Zonya \& Sano, 2019). However, adolescents are required to be able to understand and master developmental tasks (Putri, 2017). If developmental tasks can be mastered well, adolescents will feel happy, satisfied, accepted by the environment and can easily fulfil further developmental tasks (S. Y. Sari, 2017). Adolescent failure in mastering developmental tasks will lead to feelings of disappointment, frustration, feelings of failure, inhibited achievement, confusion, aggressive behaviour, compensation, identification, rationalization, projection, forming reactions, egocentric, withdrawing and experiencing impaired physical growth (Hurrelmann \& Quenzel, 2018).

The existence of adolescent developmental tasks demands major changes in the nature and patterns of individual behaviour (K. Z. Saputro, 2018). If this is not done, then the individual will experience a delay in maturity (Hurlock, 2016). There are nine tasks of adolescent development, namely the ability to build new and more mature relationships with peers, being able to perform social roles according to gender, being able to show affection for children and weak people, being able to accept their physical condition, achieving independence. or emotional maturity of adults, economically independent, able to prepare for a career, able to develop intellectual skills, have a desire to be responsible for social behaviour and have a set of values and ethical systems in behaviour (Havighurst, 1953; Hurrelmann \& Quenzel, 2018).

Adolescents often find problems in mastering developmental tasks, ranging from mild problems to severe problems. Ardi et al., (2012), said 12.89\% of adolescents tend to experience social relationship problems. Teenagers often have problems adjusting to their environment (Mataputun \& Saud, 2020). Another study explains that the problems that are often experienced by teenagers can be grouped into six, namely character problems, learning problems, online game addiction problems, fighting problems, aggressive behaviour problems and self-identity problems (Netrawati et al., 2018). The occurrence of problems in adolescents, one of which is caused by the inability of adolescents to master developmental tasks (Fitri \& Adelya, 2017; Octavia, 2020). Various efforts to assist students in mastering developmental tasks need to be carried out so that adolescents understand and master developmental tasks optimally.

Providing assistance in mastering developmental tasks is one of the basic services in guidance and counseling to students (Mariana, 2016). Guidance and counseling services that can be used to assist students in mastering developmental tasks are information services (Maulida, 2017). Information services are basically one type of service in counseling guidance that aims to provide various information, both for mastery of developmental tasks, career and work and health (I. Pratiwi et al., 2018). The main purpose of providing information services is to provide students with an understanding of various information related to education, work, personal and social development of students (Bahri et al., 2017; Maulida, 2017). Information 
services can also be used to convey various other information that is useful for students, such as educational, employment, personal, social and cultural information (Zaini et al., 2020). Another opinion explains that some of the information that can be provided through information services includes information about the school environment, social environment, good ways of learning, how to divide time in learning, types of work and conditions for entering the world of work (R. A. Sari, 2021).

The provision of information services can be done directly, indirectly and through sources (Tumanggor et al., 2019). Direct information services can be carried out classically or in groups by utilizing various methods, such as lectures, questions and answers, discussions, interviews, panel discussions and sociodrama (Rambe et al., 2017). Indirect information services can be done by utilizing various media, both print and online, such as books, brochures, posters and various online media such as the internet, YouTube, WhatsApp, Facebook and Instagram (Hidayati, 2018). Providing information services can also be done by inviting resource persons who are experts or master the information that will be conveyed to students (Muttaqin et al., 2017).

Research related to mastery of developmental tasks has been reviewed by previous researchers. The research was carried out by Jannah, (2017), stated the importance of providing understanding to adolescents about developmental tasks in an integrative way by linking Islamic values. K. Z. Saputro, (2018) explain the importance of guiding teachers to understand and know the characteristics and tasks of adolescent development. Zakiyah et al., (2018), found that the inability of adolescents to master developmental tasks is one of them caused by bullying. Fuaddillah Putra., (2017) argues that students of Islamic boarding schools have not been fully able to master developmental tasks, especially in the aspect of establishing social relations with friends, both of the same type and with different genders. Another study also found that high school-age adolescents in Singkawang mastery of developmental tasks, especially in the aspect of religious foundations, were at the individuality level (Istirahayu \& Mayasari, 2019).

Likewise, research related to information services has also been reviewed by previous researchers. Muyana, (2017) emphasizes the importance of evaluating using the Context Input Process Product (CIPP), because by using this approach, evaluation can be carried out thoroughly through a managerial system so that information services can increase, both in terms of quantity and quality of service. M. Damayanti et al., (2018) suggests that information services using image media can significantly provide students with an understanding of sex education. Noor, (2019) Noor seeks to develop internet-based information services to encourage social inclusion.

Several previous studies have shown that information services can be used for students to develop their potential, but no studies have been found that specifically discuss mastery of developmental tasks and their implications for information service materials, especially in MAN Curup. This study is still very relevant to be discussed because not all individuals are able to master developmental tasks independently (Albarello et al., 2018). Individuals, especially teenagers, need other people to be able to master developmental tasks to the fullest (Masten \& Barnes, 2018). One of the counselling services that have a very important role in helping the mastery of adolescent development tasks in schools is information services. Therefore, the information service materials provided to students must be in accordance with the needs of students to master their developmental tasks. This study aims to reveal the level of mastery of adolescent developmental tasks, especially students of MAN Curup, then explore some information service materials in order to assist adolescents in mastering developmental tasks. With this research, it is hoped that it can be used as a basic reference for supervising teachers in compiling information service materials in order to provide the understanding and help adolescents to master developmental tasks. 


\section{Methods}

This research uses a descriptive qualitative approach. The population of this study was the entire class XI Social Sciences Department, Madrasah Aliyah Negeri Curup, amounting to 75 people. The sampling technique used is saturated sampling, that is, the entire population is used as the research sample. Research data were collected using a questionnaire developed based on the following sub-variables:

1. Establish new, more mature relationships with peers, with indicators; has many friends, is trusted by friends, is able to adjust to friends, is able to get along with friends and is able to understand friends.

2. Perform social roles according to gender, with indicators; participate in useful group activities with friends of various genders, able to present themselves according to gender, able to get along with friends of different sexes, able to maintain themselves in associating with friends of different sexes and able to adjust to friends of different sexes.

3. Accept the physical state and use it effectively, with indicators; able to accept their physical condition, able to maintain body hygiene, able to maintain body health, understand and maintain reproductive health and able to protect themselves from sexual violations.

4. Achieve emotional maturity in interacting with parents and other adults, with indicators; able to develop affectionate relationships, able to develop respect, have good habits in expressing emotions, able to resolve conflicts, and can communicate politely and respectfully.

5. Have the ability to be economically independent, with indicators; able to prepare themselves to be economically independent, understand some of the jobs that can be done to make money and understand how to gain work experience.

6. Choose and prepare for a career, with indicators; understand the various types of careers and how to enter them, understand how to have a determination to the chosen career and understand how to direct oneself in education according to the demands of the chosen career.

7. Develop intellectual skills and concepts to be a good citizen, with indicators; understand concepts and skills for cooperation and mutual assistance, have a positive attitude towards religious and state laws, understand things that can damage national unity and integrity, understand the importance of mutual respect in the nation and state, and be able to maintain order in the community.

8. Responsible for social behavior, with indicators; carry out duties and responsibilities at school, help people who are in trouble, have a concern for the social environment, have a sensitive attitude towards weak people and share among others in joy and sorrow.

9. Have a set of values and an ethical system in behavior, with indicators; understand religious and ethical values in associating with peers at school, understand religious and ethical values that must be obeyed in associating with peers in society, understand religious and ethical values in associating with young people, understand how to train and develop good attitudes and understand responsibility towards self, family and society.

The alternative answer used is the Guttman scale, which is a measurement scale that uses a firm answer type or two alternative answers (Sugiono, 2019), in this study using alternative answers "yes-no". The data obtained were then analyzed using the percentage technique. This technique is based on Ridwan's opinion which states that percentage analysis is carried out by multiplying the frequency quotient by one hundred percent (Ridwan, 2017). To determine the validity of the instrument, a theoretical validity test was carried out and a reliability test was carried out with an internal consistency reliability technique. 


\section{Results and Discussion}

\section{Mastery of Curup MAN student development tasks}

In expressing the mastery of developmental tasks of MAN Curup students, the researchers grouped them into nine subvariables. The nine sub-variables include. the ability to establish new, more mature relationships with peers, perform gender-appropriate social roles, accept physical conditions and use them effectively, achieve emotional maturity in interacting with parents and other adults, have the ability to be economically independent, choose and prepare themselves in career, develop intellectual skills and concepts to become good citizens, be responsible for social behavior and have a set of values and ethical systems in behavior. To see the mastery of the developmental tasks of MAN Curup students, see the table as follows:

\section{Table 1}

Establish new, more mature relationships with peers

\begin{tabular}{|c|c|c|c|c|}
\hline \multirow{3}{*}{ Indicator } & \multicolumn{4}{|c|}{ Answer } \\
\hline & \multicolumn{2}{|c|}{ Yes } & \multicolumn{2}{|c|}{ No } \\
\hline & $\mathrm{F}$ & $\%$ & $\mathrm{~F}$ & $\%$ \\
\hline Have lots of friends & 47 & 63 & 28 & 37 \\
\hline Trusted by friends & 45 & 60 & 30 & 40 \\
\hline Able to adjust to friends & 25 & 34 & 50 & 66 \\
\hline Able to get along with friends & 20 & 27 & 55 & 73 \\
\hline Able to understand friends & 38 & 51 & 37 & 49 \\
\hline Average & \multicolumn{2}{|c|}{$47 \%$} & \multicolumn{2}{|c|}{$54 \%$} \\
\hline
\end{tabular}

Based on table 1, it can be seen that on average (54\%) MAN Curup students have not fully mastered developmental tasks related to establishing new, more mature relationships with peers. The aspect that most mastered was the ability to adjust and get along well with peers $66 \%$ and $73 \%$, respectively. However, there are several aspects that have been mastered by students, namely having lots of friends, being trustworthy and being able to understand friends when hanging out with peers, respectively $63 \%, 60 \%$ and $(51 \%)$.

\section{Table 2}

\section{Perform social roles according to gender}

\begin{tabular}{|c|c|c|c|c|}
\hline \multirow{3}{*}{ Indicator } & \multicolumn{4}{|c|}{ Answer } \\
\hline & \multicolumn{2}{|c|}{ Yes } & \multicolumn{2}{|c|}{ Tidak } \\
\hline & $\mathrm{F}$ & $\%$ & $\mathrm{~F}$ & $\%$ \\
\hline Participate in useful group activities with friends of the opposite sex & 25 & 34 & 50 & 66 \\
\hline Able to present themselves according to gender & 75 & 100 & 0 & 0 \\
\hline Able to get along with friends of different genders & 20 & 27 & 55 & 73 \\
\hline Able to maintain oneself in associating with friends of the opposite sex & 30 & 27 & 45 & 73 \\
\hline Able to adjust to friends of different genders & 75 & 100 & 0 & 0 \\
\hline Average & \multicolumn{2}{|c|}{$60 \%$} & \multicolumn{2}{|c|}{$40 \%$} \\
\hline
\end{tabular}

The results of the study as shown in table 2 show that $60 \%$ of MAN Curup students have mastered developmental tasks related to carrying out social roles according to their gender. However, students stated that there were several aspects that had not been mastered, which were related to participating in beneficial group activities with friends of the opposite sex $(66 \%)$, hanging out with friends of the opposite sex $(73 \%)$ and maintaining themselves in association with friends of different types of play (73). \%).

\section{Table 3}

Accepting the physical state and using it effectively

\begin{tabular}{|c|c|c|c|c|}
\hline \multirow{3}{*}{ Indicator } & \multicolumn{4}{|c|}{ Answer } \\
\hline & \multicolumn{2}{|c|}{ Yes } & \multicolumn{2}{|c|}{ Yes } \\
\hline & $\mathrm{F}$ & $\%$ & $\mathrm{~F}$ & $\%$ \\
\hline Able to accept the physical condition that is owned & 74 & 99 & 1 & 1 \\
\hline Able to maintain and maintain body hygiene & 74 & 99 & 2 & 3 \\
\hline Able to understand and maintain body health & 73 & 97 & 1 & 7 \\
\hline Understanding and maintaining reproductive health & 2 & 3 & 73 & 97 \\
\hline Able to protect oneself from sexual abuse & 35 & 47 & 40 & 53 \\
\hline
\end{tabular}


Table 3 shows that $52 \%$ of MAN Curup students are able to accept the physical condition and use it effectively. Some aspects of developmental tasks in this section that have been mastered are acceptance of $99 \%$ physical condition, maintaining and maintaining body hygiene (99\%), and understanding and maintaining body hygiene (97\%). While the aspects of developmental tasks that have not been fully mastered are reproductive health $(97 \%)$ and protecting oneself from sexual violations $(53 \%)$.

\section{Table 4}

Reach emotional maturity interacting with parents and other adults.

\begin{tabular}{|c|c|c|c|c|}
\hline \multirow{3}{*}{ Indicator } & \multicolumn{4}{|c|}{ Answer } \\
\hline & \multicolumn{2}{|c|}{ Yes } & \multicolumn{2}{|c|}{ Tidak } \\
\hline & $\mathrm{F}$ & $\%$ & $\mathrm{~F}$ & $\%$ \\
\hline Able to develop loving relationships with parents/adults & 74 & 99 & 1 & 1 \\
\hline Able to develop respect for parents/adults. & 74 & 99 & 1 & 1 \\
\hline Have a good habit of expressing emotions towards parents/adults. & 74 & 99 & 1 & 1 \\
\hline Able to resolve conflicts with parents/adults. & 1 & 1 & 74 & 99 \\
\hline Can communicate politely and respectfully with parents/adults. & 45 & 73 & 30 & 27 \\
\hline Average & \multicolumn{2}{|c|}{$54 \%$} & \multicolumn{2}{|c|}{$46 \%$} \\
\hline
\end{tabular}

Based on the results of the study as shown in table 4, it can be seen that about $54 \%$ of MAN Curup students already have emotional maturity in interacting with parents and other adults. The aspects of developmental tasks that are mostly mastered are developing affectionate relationships (99\%), developing respect (99\%) expressing emotions $(99 \%)$ and being able to communicate well with parents and other adults (73\%). However, there is one aspect of developmental tasks that he has not mastered, namely the ability to overcome conflicts with parents and/or adults (99\%).

Table 5

Have the ability to be economically independent

\begin{tabular}{|c|c|c|c|c|}
\hline \multirow{3}{*}{ Indicator } & \multicolumn{4}{|c|}{ Answer } \\
\hline & \multicolumn{2}{|c|}{ Yes } & \multicolumn{2}{|c|}{ Tidak } \\
\hline & $\mathrm{F}$ & $\%$ & $\mathrm{~F}$ & $\%$ \\
\hline Able to prepare themselves to be economically independent. & 0 & 0 & 75 & 100 \\
\hline Understand some of the jobs that can be done to make money. & 1 & 1 & 74 & 99 \\
\hline Understand how to gain work experience. & 4 & 5 & 71 & 95 \\
\hline Average & \multicolumn{2}{|c|}{$27 \%$} & \multicolumn{2}{|c|}{$73 \%$} \\
\hline
\end{tabular}

Mastery of developmental tasks related to the ability to be economically independent, has not been fully mastered by MAN Curup students. Based on table 5, it can be seen that about $73 \%$ of students stated that they were not economically capable. Aspects of developmental tasks that have not been mastered by many students include the ability to prepare to be economically independent (100\%), understand jobs that can make money (99\%) and how to get work experience $(93 \%)$.

\section{Table 6}

\section{Choose and prepare for a career}

\begin{tabular}{|c|c|c|c|c|}
\hline \multirow{3}{*}{ Indicator } & \multicolumn{4}{|c|}{ Answer } \\
\hline & \multicolumn{2}{|c|}{ Yes } & \multicolumn{2}{|c|}{ Tidak } \\
\hline & $\mathrm{F}$ & $\%$ & $\mathrm{~F}$ & $\%$ \\
\hline $\begin{array}{l}\text { Understand various types of careers according to talents, interests, and abilities and enter } \\
\text { them. }\end{array}$ & 15 & 20 & 60 & 80 \\
\hline Understand how to have determination in the chosen career. & 9 & 12 & 66 & 88 \\
\hline $\begin{array}{l}\text { Understand how to direct yourself in education according to the demands of the chosen } \\
\text { career. }\end{array}$ & 46 & 61 & 29 & 39 \\
\hline Average & \multicolumn{2}{|c|}{$48 \%$} & \multicolumn{2}{|c|}{$52 \%$} \\
\hline
\end{tabular}


The results of the study as shown in table 6 show that 52\% of MAN Curup students have not fully mastered developmental tasks related to careers. The aspect that has not been mastered the most is $85 \%$ related to understanding various types of careers according to their talents, interests, abilities and how to enter them. $88 \%$ of students also stated that they did not understand how to have a determination about their chosen career. However, about $61 \%$ of students already understand how to direct themselves in education to suit the demands of the chosen career.

Table 7

Develop intellectual skills and concepts to be a good citizen

\begin{tabular}{|c|c|c|c|c|}
\hline \multirow{3}{*}{ Indicator } & \multicolumn{4}{|c|}{ Answer } \\
\hline & \multicolumn{2}{|c|}{ Yes } & \multicolumn{2}{|c|}{ Tidak } \\
\hline & $\mathrm{F}$ & $\%$ & $\mathrm{~F}$ & $\%$ \\
\hline Understand the concepts and skills for cooperation and mutual assistance among others & 55 & 73 & 20 & 27 \\
\hline Have a positive attitude towards religious and state laws & 60 & 80 & 15 & 20 \\
\hline Understanding things that can damage the unity and integrity of the nation & 29 & 39 & 46 & 61 \\
\hline Understand the importance of mutual respect in the nation and state. & 74 & 99 & 1 & 1 \\
\hline Maintaining order and comfort in the community & 45 & 60 & 30 & 40 \\
\hline Average & \multicolumn{2}{|c|}{53} & \multicolumn{2}{|c|}{47} \\
\hline
\end{tabular}

The results of data analysis as shown in table 7 show that $53 \%$ of MAN Curup students have mastered developmental tasks related to skill development and several concepts to become good citizens. Judging by the indicators, $73 \%$ of students have understood several concepts and skills to work and help each other. $80 \%$ already have a positive attitude towards religious and state laws. $99 \%$ already understand the importance of mutual respect in the nation and state. However, $61 \%$ of students do not understand things that can damage unity and unity.

Table 8

Responsible for social behavior

\begin{tabular}{|c|c|c|c|c|}
\hline \multirow{3}{*}{ Indikator } & \multicolumn{4}{|c|}{ Jawaban } \\
\hline & \multicolumn{2}{|c|}{$\mathrm{Ya}$} & \multicolumn{2}{|c|}{ Tidak } \\
\hline & $\mathrm{F}$ & $\%$ & $\mathrm{~F}$ & $\%$ \\
\hline Carry out the duties and responsibilities given by the teacher & 74 & 99 & 1 & 1 \\
\hline Helping people who are in trouble & 72 & 96 & 3 & 4 \\
\hline Have a concern for the social environment & 69 & 92 & 6 & 8 \\
\hline Have a sensitive attitude towards weak people. & 35 & 47 & 40 & 53 \\
\hline Share with others in joy and sorrow. & 37 & 49 & 38 & 51 \\
\hline Average & \multicolumn{2}{|c|}{$57 \%$} & \multicolumn{2}{|c|}{$43 \%$} \\
\hline
\end{tabular}

The results of the study as shown in table 8 show that about $57 \%$ of MAN Curup students have mastered developmental tasks related to responsibility for social behavior. Aspects of developmental tasks that have been mastered are carrying out the duties and responsibilities given by the teacher $99 \%$, helping people who are in difficulty $96 \%$ and having concern for the social environment around $92 \%$. However, about 53\% do not yet have a sensitive attitude towards weak people and $51 \%$ do not yet have an attitude of sharing among others in joy and sorrow.

Table 9

\section{Have a set of values and an ethical system in behavior}

Indicator
Understanding religious and ethical values in association with peers at school.
Understand the religious and ethical values that must be obeyed in association with peers
in society
Understanding religious and ethical values in associating with young people
Understand how to train and develop a good attitude
Understanding responsibilities towards self, family, and society.
Average

\begin{tabular}{rrrr} 
& \multicolumn{2}{c}{ Answer } \\
F & Yes & \multicolumn{2}{c}{ Tidak } \\
50 & $\%$ & F & $\%$ \\
60 & 67 & 25 & 33 \\
& 80 & 15 & 20 \\
40 & 53 & 35 & 47 \\
27 & 36 & 48 & 64 \\
30 & 40 & 45 & 60 \\
\multicolumn{2}{c}{$41 \%$} & \multicolumn{2}{c}{$59 \%$} \\
\hline
\end{tabular}

The results of the study as shown in table 9 show that 59\% of MAN Curup students have not fully mastered developmental tasks related to the ownership of values and ethical systems 
in behavior. If you look at the indicators, $64 \%$ of students do not understand how to train and develop a good attitude. $60 \%$ of students do not fully understand their responsibilities towards themselves, their families and society. However, $67 \%$ of them already understand the values of religion and ethics in associating with peers. $80 \%$ of students already understand the religious and ethical values that must be obeyed in associating with peers.

Based on the results of the study, it can be seen that there are MAN Curup students who have mastered the developmental task and some have not fully mastered it. Some aspects of developmental tasks that have been mastered by MAN Curup students are performing genderappropriate roles, accepting physical conditions and utilizing them effectively, achieving emotional maturity in interacting with adults, developing intellectual skills and concepts to become good citizens. As well as being able to be responsible for social behavior. Aspects of developmental tasks that most students have not mastered include the ability to establish more mature relationships with peers, have economic independence, choose and plan careers, and have a set of values and ethical systems in behavior.

Differences in mastery of developmental tasks between one student and another and between one aspect and another are influenced by many factors including First, Heredity. Heredity is all individual potential or the totality of individual characteristics (Mubarak, 2017; Rosmawati, 2018), both physical and non-physical factors that are brought from birth and inherited genetically (Amini \& Naimah, 2020; Latifah, 2017). The results of the study show that heredity factors greatly affect a person's intellectual and personality development (Amini $\&$ Naimah, 2020). Second, Maturity or maturity. Maturity is the functioning of all body organs both physically and psychologically due to growth and development (Jackson \& Goossens, 2020). Maturity means the achievement of the process of growth and development (Aridhona, 2017). Another opinion explains that maturity is the readiness of individuals in carrying out developmental tasks (R. S. Damayanti et al., 2018). Maturity in addition to influencing the mastery of developmental tasks, will also give birth to similarities in individual growth and development (Kristina et al., 2019). Third, Environment. The environment is everything that comes from outside the individual, which includes the inner environment (food eaten) and the external environment (Sutarto, 2019). The results of the study show emotional maturity (Miyanti \& Ismiradewi, 2020), social support (Apriani, 2019; Y. A. Saputro \& Sugiarti, 2021), parenting style (Candrawati, 2019), family environment (Andriyani, 2020; D. Safitri, 2018) and school environment (Mustikasari \& Effendy, 2020) also affect the mastery of adolescent developmental tasks. In addition, the lack of optimal counseling services received by students in schools is also believed to influence the achievement of mastery of adolescent developmental tasks, such as group counseling services with Cognitive Restructuring techniques (Abdi \& Mafirja, 2019).

In the past, the issue of influencing factors affecting developmental tasks was very developed, resulting in various theories, such as the theory of nativism, empiricism and convergence (K. Z. Saputro, 2018; Setyowati, 2018). The theory of nativism explains that individual development is influenced by hereditary factors and occurs naturally in line with maturity (Luin et al., 2019). While the theory of empiricism says that individual development is strongly influenced by the environment, both the internal, natural and social environment (Sholichah, 2018). Therefore, individual experience has a very important role in helping mastery of developmental tasks (Fahrizal, 2020). Pengalaman individu diperoleh melalui interaksi individu dengan lingkungan, baik family, school and community. In contrast to the convergence theory, this theory argues that individual growth and development is influenced by heredity, maturity and environmental factors that interact with each other (Arifin, 2020; Luin et al., 2019). Each individual has differences in nature, maturity and experience, the result is the mastery of individual development tasks that differ from one individual to another. 


\section{Implications of mastery of developmental tasks on information service programs}

The description of the results of research on the mastery of developmental tasks of MAN Curup students can be used as a reference in preparing a counseling guidance program, especially in compiling information service materials. This is important to do, so that the information services provided to students can really help students in achieving developmental tasks. Based on the results of research conducted by researchers, important aspects that can be used as material in information services are as follows:

1. Establish new, more mature relationships with peers. This aspect includes how to adjust and get along with peers.

2. Performing social roles according to gender, including how to get along well with friends of the opposite sex and how to take care of yourself in association with peers of the opposite sex.

3. Understanding of physical conditions and how to use them effectively. This aspect includes maintaining reproductive health and protecting oneself from sexual violations.

4. Cultivate independence and emotional maturity in interacting with parents and adults. This aspect includes how to deal with conflicts with parents and other adults and how to communicate well with adults.

5. The ability to be economically independent, including how to prepare to be economically independent, the types of work teenagers can do to earn money and how to get work experience.

6. Choose and prepare for a career. This aspect includes the types of careers and how to enter them, how to choose a career and how to establish yourself in the chosen career.

7. Develop intellectual skills and concepts in order to become good citizens, including concepts and skills of cooperation and mutual assistance among others and the unity of the nation as well as things that can damage it.

8. Responsible for social behavior, including cultivating a sensitive attitude towards weak people and fostering an attitude of sharing among others.

9. Values and value systems in behavior, including responsibility for oneself, family and society, training and developing good attitudes and ethics in socializing among young people.

10. Preparation of guidance and counseling service programs in schools, including information services, based on student needs (Sumitri et al., 2017). Therefore, the first step that must be taken by the supervising teacher before preparing the program is to conduct a need assessment or identify the needs of students (Farozin et al., 2017). It is important to do a need assessment before the preparation of the counseling guidance program in schools (Afiat et al., 2021). This is so that the counseling guidance service really fits the needs of students, both to develop their potential and to alleviate the problems they face, including to help students master developmental tasks (Fadoli et al., 2020).

In fact, the counseling service program in schools has not been prepared based on a need assessment. As a result, the guidance and counseling services provided to students have less significant impact in developing their potential and assisting students in mastering developmental tasks. In providing career information services, for example, it must be in accordance with the needs and interests of students. This is in line with Hurent's opinion which explains several important aspects that need to be considered in providing career information, namely the level of interest and needs of students towards careers Hunt et al., (2017). Likewise with regard to social relations, values, value systems, developing emotional maturity and an 
attitude of responsibility, establishing relationships with peers and with opponents must be designed according to what students need.

\section{Conclusions and Suggestions}

Madrasah Aliyah Negeri Curup students who are in their teens, when viewed from the nine aspects of developmental tasks, some have mastered and some have not mastered optimally. Some of the developmental tasks that have been mastered are displaying roles according to gender, accepting physical conditions, showing emotional maturity in interacting, understanding various concepts to become good citizens and being responsible for social behavior. Developmental tasks that have not been mastered include not having maturity in relationships with peers, not being economically independent, not being able to choose and planning a career properly and not understanding and implementing a value system and ethics in behavior. The existence of several adolescent developmental tasks that have not been mastered by students, has implications for the preparation of information service materials. Developmental tasks that have not been mastered by students should be made a top priority for information service materials. So that the information services provided are really useful for students, especially in helping master the tasks of adolescent development.

\section{References}

Abdi, S., \& Mafirja, S. (2019). Pelaksanaan Konseling Kelompok menggunakan Teknik Cognitive Restructuring untuk Meningkatkan Penyesuaian Diri Siswa SMA Dayah Inshafudin Banda Aceh. Bulletin of Counseling and Psychotherapy, 1(2), 46-52.

Afiat, Y., Fitriani, W., \& Aisyah, T. F. (2021). Need Assesment sebagai Manifestasi Unjuk Kerja Konselor. Al-Tazkiah: Jurnal Bimbingan Dan Konseling Islam, 10(1), 1-20.

Albarello, F., Crocetti, E., \& Rubini, M. (2018). I and us: A longitudinal study on the interplay of personal and social identity in adolescence. Journal of Youth and Adolescence, 47(4), 689-702.

Ali, M., \& Asrori, M. (2014). Psikologi Remaja. Bumi Aksara.

Amini, N., \& Naimah, N. (2020). Faktor hereditas dalam mempengaruhi perkembangan intelegensi anak usia dini. Jurnal Buah Hati, 7(2), 108-124.

Andriyani, J. (2020). Peran lingkungan keluarga dalam mengatasi kenakalan remaja. AtTaujih: Bimbingan Dan Konseling Islam, 3(1), 86-98.

Apriani, M. (2019). Pengaruh dukungan sosial teman sebaya dan regulasi diri terhadap penyesuaian diri santri. Jurnal Harkat: Media Komunikasi Gender, 11(2), 160-171.

Ardi, Z., Ibrahim, Y., \& Said, A. (2012). Capaian Tugas Perkembangan Sosial Siswa dengan Kelompok Teman Sebaya dan Implikasinya terhadap Program Pelayanan Bimbingan dan Konseling. Konselor, 1(2), Article 2. https://doi.org/10.24036/0201212522-0-00

Aridhona, J. (2017). Hubungan antara kecerdasan spiritual dan kematangan emosi dengan penyesuaian diri remaja. Intuisi: Jurnal Psikologi Ilmiah, 9(3), 224-233.

Arifin, Z. (2020). Teori Perkembangan Sosial Anak dan Pengaruhnya Bagi Pendidikan. TADARUS, 9(1). 
Bahri, S., Alam, A. A., \& Supiati, S. (2017). Pengaruh Layanan Informasi Bidang Bimbingan Sosial Terhadap Perkembangan Perilaku Sosial Siswa. Jurnal Konseling Andi Matappa, 1(1), 30-38.

Batubara, J. R. (2016). Adolescent development (perkembangan remaja). Sari Pediatri, 12(1), 21-29.

Candrawati, D. (2019). Persepsi terhadap pola asuh demokratis dan konsep diri terhadap penyesuaian diri pada mahasiswa. Psikostudia: Jurnal Psikologi, 8(2), 99-107.

Damayanti, M., Anni, C. T., \& Mugiarso, H. (2018). Layanan Informasi dengan Media Gambar untuk Meningkatkan Pemahaman Sex Edukation Siswa. Indonesian Journal of Guidance and Counseling: Theory and Application, 7(1), Article 1. https://doi.org/10.15294/ijgc.v7i1.17879

Damayanti, R. S., Sovitriana, R., Nilawati, E., \& Widyayani, F. A. (2018). Konformitas Dan Kematangan Emosi Dengan Perilaku Agresi Siswa Smk Di Jakarta Timur. IKRA-ITH HUMANIORA: Jurnal Sosial Dan Humaniora, 2(3), 74-79.

Diananda, A. (2019). Psikologi remaja dan permasalahannya. ISTIGHNA: Jurnal Pendidikan Dan Pemikiran Islam, 1(1), 116-133.

Fadoli, R. S., Habibra, M., \& Arpeni, D. (2020). Need Assessment Based on Digital Devices for Development of Guidelines and Counseling Programs In 4.0 Era. Proseding IAIN Batusangkar, 1(1), 205-212.

Fahrizal, M. A. (2020). Teori-teori Pendidikan dalam Aliran Klasik.

Farozin, M., Suwarjo, S., \& Astuti, B. (2017). Identifikasi permasalahan perancangan program bimbingan dan konseling pada guru SMK di Kota Yogyakarta. Jurnal Penelitian Ilmu Pendidikan, 10(1), 40-52.

Fataruba, D. (2017). Penerapan Layanan Informasi Untuk Meningkatkan Minat Belajar Siswa Sekolah Menengah Atas. Jurnal Bimbingan Dan Konseling Terapan, 1(1).

Fatchurahman, M. (2017). Konsep Dasar Evaluasi Program Bimbingan dan Konseling. Palangka Raya: Lembaga Literasi Dayak.

Fatmawaty, R. (2017). Memahami Psikologi Remaja. Reforma: Jurnal Pendidikan Dan Pembelajaran, 6(2).

Fellasari, F., \& Lestari, Y. I. (2017). Hubungan antara pola asuh orangtua dengan kematangan emosi remaja. Jurnal Psikologi, 12(2), 84-90.

Fhadila, K. D. (2017). Menyikapi perubahan perilaku remaja. JPGI (Jurnal Penelitian Guru Indonesia), 2(2), 16-23.

Firman, F. (2018). Efektivitas layanan penguasaan konten melalui bimbingan kelompok belajar dalam mengurangi perilaku menyontek siswa saat ujian.

Fitri, N. F., \& Adelya, B. (2017). Kematangan emosi remaja dalam pengentasan masalah. JPGI (Jurnal Penelitian Guru Indonesia), 2(2), 30-39. https://doi.org/10.29210/02225jpgi0005

Fitriyanti, E., Solihatun, S., \& Ardianti, T. (2020). Kontribusi Layanan Penguasaan Konten dalam Meningkatkan Sikap Empati Siswa. Consilium: Berkala Kajian Konseling Dan Ilmu Keagamaan, 6(2), 63-75. 
Fuaddillah Putra., M. P. (2017). Ketercapaian Tugas-tugas Perkembangan Siswa Pondok Pesantren Dan Implikasinya Dalam Bimbingan dan Konseling. Jurnal Counseling Care, 1(1), 27-34. https://doi.org/10.22202/jcc.2017.v1i1.1990

Hafiza, S., \& Mawarpury, M. (2018). Pemaknaan Kebahagiaan oleh Remaja Broken Home. Psympathic: Jurnal Ilmiah Psikologi, 5(1), 59-66.

Hasibuan, M. F. (2018). Efektivitas Layanan Informasi Dengan Menggunakan Pendekatan Contextual Teaching And Learning Dalam Mengurangi Sikap Siswa Terhadap Gaya Hidup Hedonisme. Jurnal Bimbingan Dan Konseling Ar-Rahman, 4(1), 1-10.

Havighurst, R. J. (1953). Human development and education (pp. ix, 338). Longmans, Green.

Hidayati, A. (2018, October 10). Layanan informasi belajar berbasis multimedia. 1st ASEAN School Counselor Conference on Innovation and Creativity in Counseling. 1st ASEAN School Counselor Conference on Innovation and Creativity in Counseling. https://www.gci.or.id/proceedings/view_article/174/3/ascc-2017

Hunt, J. M., Langowitz, N., Rollag, K., \& Hebert-Maccaro, K. (2017). Helping students make progress in their careers: An attribute analysis of effective vs ineffective student development plans. The International Journal of Management Education, 15(3), 397408. https://doi.org/10.1016/j.ijme.2017.03.017

Hurlock, E. B. (2016). Psikologi Perkembangan, Suatu Pendekatan Sepanjang Rentang Kehidupan. Erlangga.

Hurrelmann, K., \& Quenzel, G. (2018). Developmental Tasks in Adolescence. Routledge. https://doi.org/10.4324/9780429452055

Istirahayu, I., \& Mayasari, D. (2019). Identifikasi tingkat perkembangan remaja siswa SMA di kota Singkawang pada aspek landasan hidup religius [Preprint]. INA-Rxiv. https://doi.org/10.31227/osf.io/zekac

Jackson, S., \& Goossens, L. (2020). Handbook of adolescent development.

Jannah, M. (2017). Remaja dan tugas-tugas perkembangannya dalam Islam. Psikoislamedia: Jurnal Psikologi, 1(1).

Karlina, L. (2020). Fenomena terjadinya Kenakalan Remaja. Jurnal Edukasi Nonformal, 1(2), $147-158$.

Katharina, T., \& Yuliana, Y. (2018). Pengaruh Penyuluhan Kesehatan Reproduksi melalui Audio Visual dengan Hasil Pengetahuan Setelah Penyuluhan pada Remaja SMA Negeri 2 Pontianak Tahun 2017. Jurnal Kebidanan, 8(1), 265367.

Khasanah, S. M. R., \& Mamnuah, M. (2021). Tingkat Stres Berhubungan dengan Pencapaian Tugas Perkembangan pada Remaja. Jurnal Ilmu Keperawatan Jiwa, 4(1), 107-116. https://doi.org/10.32584/jikj.v4i1.726

Kristina, A. Y., Eva, N., \& Bisri, M. (2019). Pengaruh Kematangan Emosi Terhadap Penyesuaian Sosial Pada Mahasiswa Baru Politeknik Negeri Malang. Jurnal Sains Psikologi, 8(1), 187-192.

Kusuma, R. S. (2017). Komunikasi antar pribadi sebagai solusi konflik pada hubungan remaja dan orang tua di SMK Batik 2 Surakarta. Warta LPM, 20(1), 49-54.

Latifah, U. (2017). Aspek perkembangan pada anak Sekolah Dasar: Masalah dan perkembangannya. Academica: Journal of Multidisciplinary Studies, 1(2), 185-196. 
Lestari, I. (2017). Meningkatkan Kematangan Karir Remaja melalui Bimbingan Karir Berbasis Life Skills. 3(1), 11.

Luin, A. T., Lian, B. S., \& Paulus, R. W. (2019). Teori Nativisme Terhadap Pola Asuh Orang Tua Dan Perkembangan Anak.

Maghfur, S. (2018). Bimbingan Kelompok Berbasis Islam untuk Meningkatkan Penyesuaian Diri Santri Pondok Pesantren Al Ishlah Darussalam Semarang. KOMUNIKA: Jurnal Dakwah Dan Komunikasi, 12(1), 85-104.

Mariana, D. (2016). Membentuk Karakter Cerdas Melalui Bimbingan Dan Konseling Perkembangan Untuk Menghadapi MEA. JBKI (Jurnal Bimbingan Konseling Indonesia), 1(1), 14. https://doi.org/10.26737/jbki.v1i1.101

Marwoko, G. (2019). Psikologi Perkembangan Masa Remaja. Tasyri: Jurnal TarbiyahSyariah-Islamiyah, 26(1), 60-75.

Masten, A. S., \& Barnes, A. J. (2018). Resilience in children: Developmental perspectives. Children, 5(7), 98.

Mataputun, Y., \& Saud, H. (2020). Analisis komunikasi interpersonal dan penyesuaian diri remaja. Jurnal Konseling dan Pendidikan, 8(1), 32-37. https://doi.org/10.29210/140800

Maulida, N. (2017). Pengaruh Layanan Informasi tentang Tugas Perkembangan Remaja terhadap Pemahaman Tugas-tugas Perkembangan di SMA. Jurnal Pendidikan Dan Pembelajaran Khatulistiwa,

$6(10)$ https://jurnal.untan.ac.id/index.php/jpdpb/article/view/22251

Miyanti, M. A., \& Ismiradewi, I. (2020). Hubungan Kematangan Emosi dengan Penyesuaian Diri pada Siswa. Prosiding Seminar Nasional Magister Psikologi Universitas Ahmad Dahlan, 1, 33-42.

Mubarak, A. Z. (2017). Perkembangan Jiwa Agama. ITTIHAD, 12(22), 91-106.

Mustikasari, S., \& Effendy, H. V. (2020). Hubungan Lingkungan Sekolah dengan Penyimpangan Perilaku pada Remaja Awal Usia 13-14 Tahun di SMPN Mojoanyar. Journals of Ners Community, 11(1), 52-60.

Mustofa, A. (2017). Mekanisme Koping pada Remaja. Journal of Holistic and Traditional Medicine, 2(02), 156-160.

Muttaqin, R., Wagimin, W., \& Tadjri, I. (2017). Keefektifan Layanan Informasi Karier Berbantuan Video Interaktif dan Live Modeling untuk Meningkatkan Pemahaman Karier Siswa SMP. Jurnal Bimbingan Konseling, 6(2), 174-179. https://doi.org/10.15294/jubk.v6i2.21794

Muyana, S. (2017). Context Input Process Product (CIPP): Model Evaluasi Layanan Informasi. Prosiding Seminar Bimbingan Dan Konseling, 1(1), 342-347.

Nazir. (2015). Metode Penelitian. Ghalia Indonesia.

Nessi Meilan, S. S. T., Maryanah, A. M., \& Willa Follona, S. S. T. (2019). Kesehatan Reproduksi Remaja: Implementasi PKPR dalam Teman Sebaya. Wineka Media.

Netrawati, N., Khairani, K., \& Karneli, Y. (2018). Upaya Guru BK untuk Mengentaskan Masalah-Masalah Perkembangan Remaja dengan Pendekatan Konseling Analisis Transaksional. Islamic Counseling : Jurnal Bimbingan dan Konseling Islam, 2(1), 7990. https://doi.org/10.29240/jbk.v2i1.463 
Noor, M. U. (2019). Aplikasi Layanan Informasi Berbasis Internet untuk Menumbuhkan Inklusi Sosial di Perpustakaan Daerah. JIPI (Jurnal Ilmu Perpustakaan dan Informasi), 4(1), 84-95. https://doi.org/10.30829/jipi.v4i1.4122

Nurhaliza, D., Zaini, A., \& Dianto, M. (2021). Profil Perkembangan Kognitif Peserta Didik di Kelas VII MTs. Subulussalam Sayur Maincat Kecamatan Kotanopan Kabupaten Mandailing Natal Sumatera Utara. Mudabbir (Journal Research And Education Studies), 1(1), 51-60.

Octavia, S. A. (2020). Motivasi belajar dalam perkembangan remaja. Deepublish.

Pratiwi, I., Astuti, I., \& Yuline, Y. (2018). Layanan Informasi oleh Guru Pembimbing Tentang Tugas Perkembangan Remaja Siswa Kelas X SMA Negeri 9 Pontianak. Jurnal Pendidikan Dan Pembelajaran Khatulistiwa, https://jurnal.untan.ac.id/index.php/jpdpb/article/view/26881

Pratiwi, W. R., Hamdiyah, H., \& Asnuddin, A. (2020). Deteksi Dini Masalah Kesehatan Reproduksi Melalui Pos Kesehatan Remaja. Jurnal Inovasi Hasil Pengabdian Masyarakat (JIPEMAS), 3(1), 87-94.

Putri, S. R. (2017). Pengaruh Konseling Kelompok terhadap Penurunan Masalah Diri Pribadi Siswa SMA Negeri 6 Padang. Jurnal Penelitian Bimbingan Dan Konseling, 2(1).

Rambe, S. A., Mudjiran, M., \& Marjohan, M. (2017). Pengembangan Modul Layanan Informasi untuk Mengembangkan Kontrol Diri dalam Penggunaan Smartphone. Konselor, 6(4), 132-137. https://doi.org/10.24036/02017648051-0-00

Ridwan. (2017). Dasar-dasar Statistik. Alfabeta.

Romi, F. T., Neviyarni, \& Firman. (2018). Layanan Informasi dalam Peningkatan Keterampilan Belajar Mahasiswa STKIP PGRI Sumatera Barat. https://jurnal.untirta.ac.id/index.php/JPBK/article/view/3937

Rosmawati, R. (2018). Perkembangan Peserta Didik (Psikologi Perkembangan Remaja). wahyu sari yeni.

Safitri, D. (2018). Identifikasi Faktor yang Mempengaruhi Penyesuaian Diri Siswa yang Memiliki Prestasi Belajar Rendah di Kelas VII SMP Negeri 8 Kota Jambi. Penyesuaian Dri.

Safitri, N. E., \& Putranti, D. (2017). Assessment Kebutuhan Pedoman Penyusunan Program Bimbingan dan Konseling Komprehensif pada Guru Bimbingan dan Konseling Tingkat SMK di Kota Yogyakarta. G-Couns: Jurnal Bimbingan Dan Konseling, 1(2).

Saputro, K. Z. (2018). Memahami ciri dan tugas perkembangan masa remaja. Aplikasia: Jurnal Aplikasi Ilmu-Ilmu Agama, 17(1), 25-32.

Saputro, Y. A., \& Sugiarti, R. (2021). Pengaruh Dukungan Sosial Teman Sebaya dan Konsep Diri terhadap Penyesuaian Diri pada Siswa SMA Kelas X. Philanthropy: Journal of Psychology, 5(1), 59-72.

Sari, R. A. (2021). Pendekatan Dan Model Pelayanan BK Pola 17 Plus Jenis Pelayanan BK. OSF Preprints. https://doi.org/10.31219/osf.io/z2sjg

Sari, S. Y. (2017). Tinjauan Perkembangan Psikologi Manusia pada Usia Kanak-Kanak dan Remaja. Primary Education Journal (PEJ), 1(1), 46-50. 
Sartika, M., \& Yandri, H. (2019). Pengaruh layanan bimbingan kelompok terhadap konformitas teman sebaya. Indonesian Journal of Counseling and Development, 1(1), 9-17.

Sebayang, W., Gultom, D. Y., \& Sidabutar, E. R. (2018). Perilaku seksual remaja. Deepublish.

Setyowati, W. (2018). Studi Pencapaian Tugas Perkembangan Remaja pada Siswa-siswi SMAN 1 Porong. Hospital Majapahit (Jurnal Ilmiah Kesehatan Politeknik Kesehatan Majapahit Mojokerto), 10(1).

Sholichah, A. S. (2018). Teori-teori pendidikan dalam Al-Qur'an. Edukasi Islami: Jurnal Pendidikan Islam, 7(01), 23-46.

Sugiono. (2019). Metode penelitian pendidikan: Pendekatan kuantitatif, kualitatif dan $R \& D$, . Alfabeta.

Sumitri, F., Rohiat, R., \& Zakaria, Z. (2017). Pengelolaan Program Bimbingan dan Konseling di Sekolah Menengah Atas. Manajer Pendidikan, 11(6).

Sutarto, S. (2019). Lingkungan Pendidikan Dalam Perspektif Al Qur'an Dan Implikasinya Terhadap Pertumbuhan Dan Perkembangan Anak. Edukasi Islami: Jurnal Pendidikan Islam, 8(02), 287-308.

Syaifullah, B. H., \& Purwoko, B. (2019). Pengembangan Aplikasi Need Assessment Siswa untuk Penyusunan Progam BK di SMP. Jurnal BK UNESA, 10(3).

Tumanggor, H. R., Sunawan, S., \& Purwanto, E. (2019). Keefektifan Layanan Informasi Karir Berbantuan Website untuk Meningkatkan Perencanaan Karir Siswa SMA Di Kota Tarakan. Jurnal Bimbingan dan Konseling Ar-Rahman, 4(1), 11-17. https://doi.org/10.31602/jbkr.v4i1.1348

Wahidin, U. (2017). Pendidikan Karakter Bagi Remaja. Edukasi Islami: Jurnal Pendidikan Islam, 2(03).

Yasipin, Y., Rianti, S. A., \& Hidaya, N. (2020). Peran Agama dalam Membentuk Kesehatan Mental Remaja. Manthiq, 5(1), 25-31. https://doi.org/10.29300/mtq.v5i1.3240

Zaini, A., Dianto, M., \& Mulyani, R. R. (2020). Pentingnya Penggunaan Media Bimbingan dan Konseling dalam Layanan Informasi. Prosiding Seminar Nasional Bimbingan Dan Konseling Universitas Negeri Malang, O(0), 126-131.

Zakiyah, E. Z., Fedryansyah, M., \& Gutama, A. S. (2018). Dampak bullying pada tugas perkembangan remaja korban bullying. Focus: Jurnal Pekerjaan Sosial, 1(3), 265-279.

Zonya, O. L., \& Sano, A. (2019). Differences in The Emotional Regulation of Male and Female Students. Jurnal Neo Konseling, 1(3), Article 3. https://doi.org/10.24036/00128kons2019 
